\title{
Microfoil boom application of picloram and 2,4-D for leafy spurge (Euphorbia esula) control $^{1}$
}

\author{
RODNEY G. LYM
}

The author is Assoc. Prof., Crop Weed Sci. Dep., N.D. State Univ., Fargo, ND 58105.

\begin{abstract}
:
Leafy spurge control with picloram and various 2,4-D formulations was evaluated to determine the optimum treatment combination and carrier volume for aerial application using a microfoil boom. Leafy spurge control was similar when the same herbicide treatments were applied at 94 and $47 \mathrm{~L} /$ ha but declined at $23 \mathrm{~L} /$ ha. Leafy spurge control was better when similar herbicide treatments were applied with a one-row microfoil nozzle boom compared to a two-row nozzle. Leafy spurge control 12 months after treatment tended to be better with picloram at 0.28 and $0.56 \mathrm{~kg}$ ae/ha applied with 2,4-D mixed amine compared to picloram plus 2,4-D dimethylamine or oil-soluble amine formulations during average growing conditions. However, picloram plus 2,4-D oil-soluble amine was the best formulation in dry conditions.
\end{abstract}

\section{Nomenclature:}

2,4-D (2,4-dichlorophenoxy) acetic acid; picloram, 4-amino-3,5,6-trichloro-2-pyridinecarboxylic acid; leafy spurge, Euphorbia esula L. \#² EPHES.

\footnotetext{
${ }^{1}$ Received for publication Oct. 5, 1988, and in revised form March 2, 1989. Published with the approval of the Director, Agric. Exp. Stn., N.D. State Univ., as J. Art. No. 1726.

${ }^{2}$ Letters following this \# symbol are a WSSA-approved computer code from Composite List of Weeds, Weed Sci. 32 , Suppl. 2. Available from WSSA, 309 W. Clark St., Champaign, IL 61820.
} 


\section{Introduction}

Leafy spurge infests over 400,000 ha in North Dakota, primarily on untilled land such as pastures, woodlands, roadsides, farmsteads, and house lots (8). North Dakota has approximately 5.3 million ha of untilled land, so the present infestation represents only $7.5 \%$ of the land most likely to become infested with leafy spurge. North Dakota began a cost-share program in 1981 to help defray herbicide expenses for leafy spurge control. Over 100,000 ha of pasture and rangeland were treated for leafy spurge control in North Dakota in 1987 alone ${ }^{3}$. Picloram plus 2,4-D at 0.28 plus $1.1 \mathrm{~kg}$ ae/ha applied annually provides the most cost-effective leafy spurge control in North Dakota (5). Leafy spurge control increased from 20 to $30 \%$ when picloram at $0.28 \mathrm{~kg} / \mathrm{ha}$ was applied with 2,4-D compared to picloram alone $(5,6)$. Picloram plus $2,4-\mathrm{D}$ applied at these relatively low rates averaged 50 to $70 \%$ leafy spurge control $12 \mathrm{MAT}^{4}$ but increased to $90 \%$ or more when applied annually for 3 to 4 years $(4,5,6)$. Leafy spurge control has been similar regardless of which 2,4-D formulation was used in combination with picloram $(3,7)$.

Herbicides generally have been applied with ground equipment in North Dakota; however, helicopters have been used in the more rugged areas to treat approximately 20,000 ha annually. Nearly all aerial applications by helicopter are made using a microfoil $^{5}$ nozzle boom which produces large, uniformly sized droplets and has minimal spray drift compared to conventional aircraft spray nozzles $(1,2)$. Each microfoil nozzle is 15 $\mathrm{cm}$ long and contains 60 (single-row) or 120 (double-row) needlelike orifices protruding from the trailing edge (Figure 1). The nozzle of the microfoil is shaped like an airfoil and the entire boom is similar to an airplane wing (Figure 2).

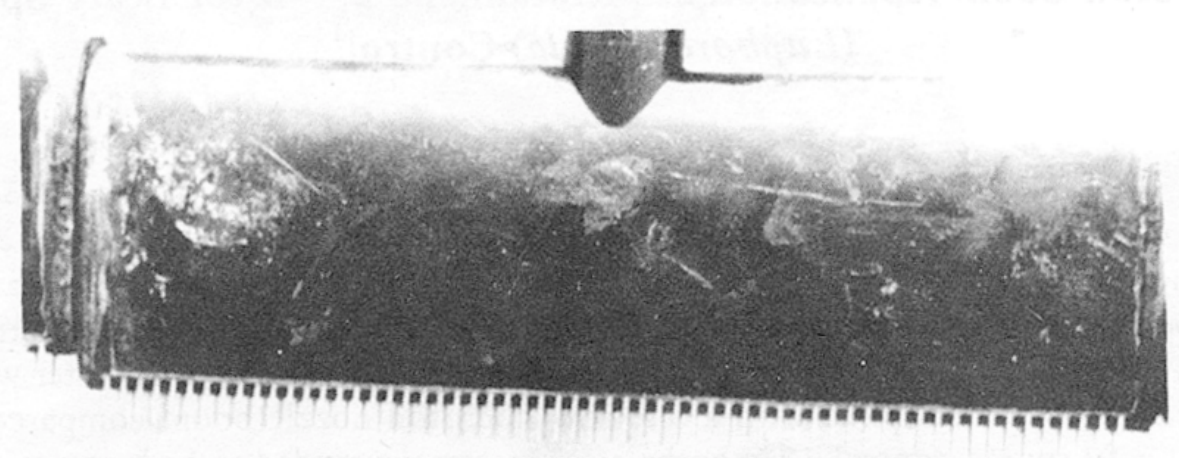

Figure 1. A double needle- row microfoil nozzle. The back row of needles appear as shadows.

\footnotetext{
${ }^{3}$ N.D. State Dep. Agric. 1988. Personal communication. Bismarck, ND 58202.

${ }^{4}$ Abbreviations: MAT $=$ months after treatment.

${ }^{5}$ Registered trademark of Rhone-Poulenc Ag Co., Alexander Drive, Research Triangle Park, NC 27709
} 


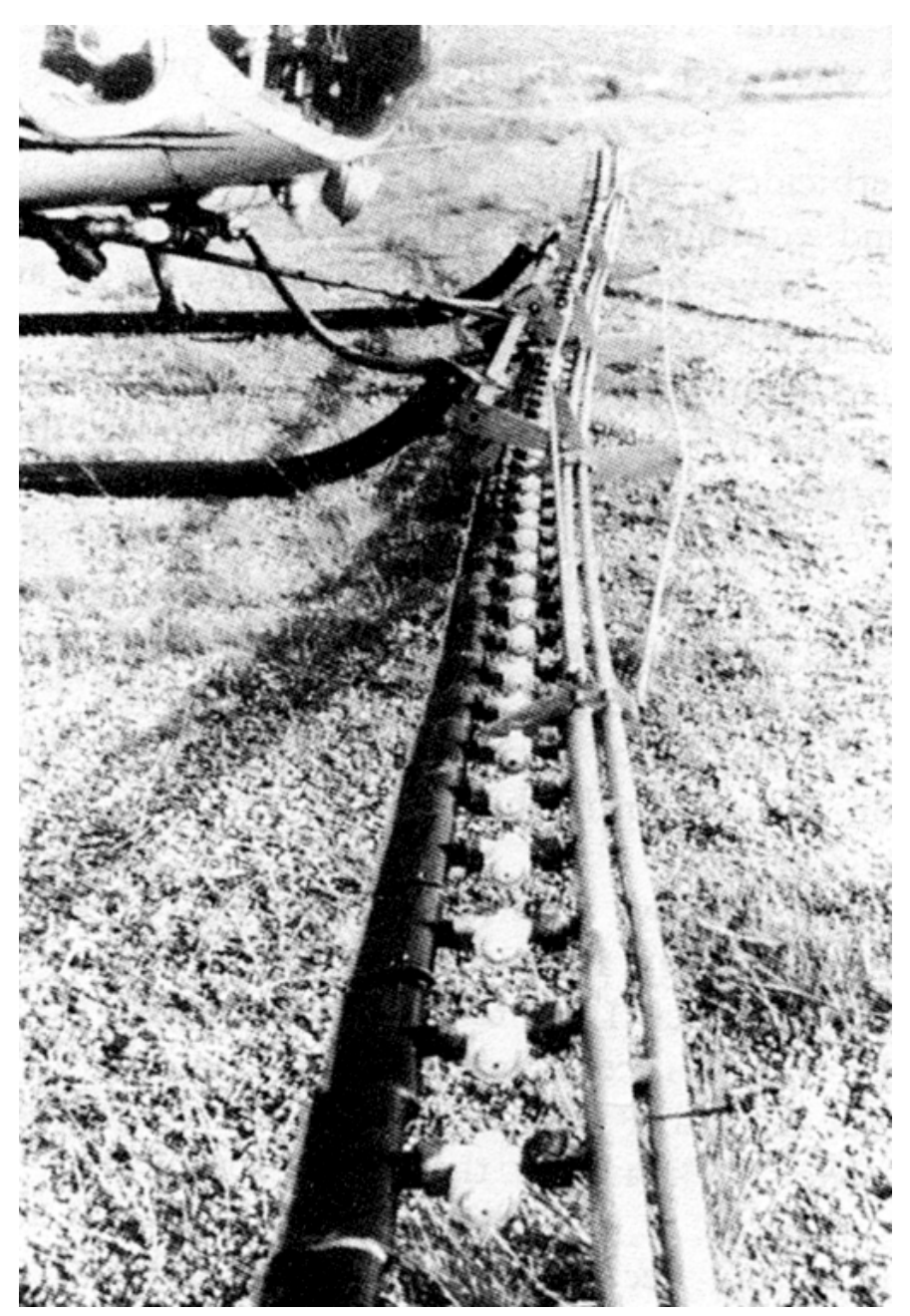

Figure 2. Helicopter equipped with an 8-m long microfoil boom with 52 nozzles.

The single-row nozzles produce 800 to $1000 \mu \mathrm{m}$ droplets through a $0.33-\mathrm{mm}$ orifice. The double-row nozzles produce 1400 to $1700 \mu \mathrm{m}$ droplets through a $0.7-\mathrm{mm}$ orifice. There are two nozzles $/ 30 \mathrm{~cm}$ of boom, and a control unit in the center allows the pilot to maintain the boom 180 degrees into the airstream $(1,2)$. This produces a straight swath pattern, and because the nozzles produce few fine spray droplets that drift, application within a few meters of non-target plants such as trees and near surface water is possible.

A drawback to using the microfoil boom is that it requires much higher volumes than conventional aerial application equipment. Generally, picloram plus 2,4-D amine at 0.56 plus $1.1 \mathrm{~kg} / \mathrm{ha}$, respectively, have been applied using a spray volume of $94 \mathrm{~L} / \mathrm{ha}$. Since aerial application is expensive (approximately $\$ 425 / \mathrm{h}$ ), reduced application volume would increase the cost-effectiveness by reducing time spent on the ground reloading the sprayer tanks.

The purpose of this research was to evaluate leafy spurge control from picloram plus 2,4-D applied with different 2,4-D formulations through a microfoil nozzle boom using several application volumes and two nozzle types. 


\section{Materials and methods}

The experiment was established on ungrazed rangeland near Kenmare and Mandan, ND. Both sites had at least an $80 \%$ ground cover of leafy spurge and no history of herbicide application. The soil at Kenmare was a Velva loam on nearly level terrain and at Mandan, a Grail-Moline silt loam overlaying coarse sand and gravel on a slope of 2 to 4 degrees. These sites were sprayed June 18, 1985, and June 23, 1987, respectively.

Picloram at 0.28 or $0.56 \mathrm{~kg} / \mathrm{ha}$ was applied with 2,4-D dimethylamine, oil-soluble amine (4:1 dodecylamine:tetradecylamine, $\mathrm{v} / \mathrm{v})$ or mixed amine (2:1 dimethylamine:diethanolamine, $\mathrm{v} / \mathrm{v}$ ) formulations at $1.1 \mathrm{~kg} / \mathrm{ha}$. Treatments were applied using a helicopter ${ }^{6}$ equipped with an 8-m long microfoil boom with 52 single- or double-row needle-nozzles. Herbicides were applied at 23,47 , or $94 \mathrm{~L} / \mathrm{ha}$ at 140 to $280 \mathrm{kPa}$ depending on application volume and nozzle type. A tractor-mounted sprayer delivering $47 \mathrm{~L} / \mathrm{ha}$ water at $240 \mathrm{kPa}$ with 80005 nozzles $^{7}$ was used to apply the ground-level treatment.

The plots were 4.5 by 15 and 4.5 by 9 in at the Kenmare and Mandan locations, respectively. Each treatment was replicated four times in a randomized complete block design. Before herbicide application, the plots were covered individually with $0.23-\mathrm{mm}$ black plastic tarps. Each tarp was held in place with 8 to $100.9-\mathrm{cm}$ diam by $46-\mathrm{cm}$ long cane-shaped steel rods staked on the inside edge. A grommet was made from strips of 7.6-cm-wide filament tape placed on both sides of the plastic tarp to prevent tearing.

The tarps covering the four plots to be treated were removed immediately before and were replaced following application (Figure 3). The spray solution had dried on the plants before the tarps were replaced, and it is unlikely a significant amount of herbicide adhered to the bottom of the tarps. The ground-level application was last, and the tarps were not replaced. Care was taken to prevent tarps from contacting herbicide present on the other tarps during removal and replacement. The tarps effectively prevented treatment overlap because the plants in the untreated plots had no herbicide injury symptoms and the borders were precise (Figure 4).

Occasionally, only two or three plots of each treatment were uncovered for a flyover by the helicopter to prevent double coverage. For example, a plot in the first replication could be completely treated in one flyover, but only one-half of a plot in another replication could have been treated. The plots which would be partially treated remained covered during the first flyover and were uncovered for a second flyover. Plots uncovered for the first flyover were covered during the second. The treatments were applied from 6 to 9 p.m., and then all tarps were removed.

\footnotetext{
${ }^{6}$ Bell Helicopter, Inc. Series 47-G4A, P.O. Box 482, Ft. Worth, TX 76101.

${ }^{7}$ Spraying Systems Co., North Ave. at Schmale Rd., Wheaton, IL 60187.
} 


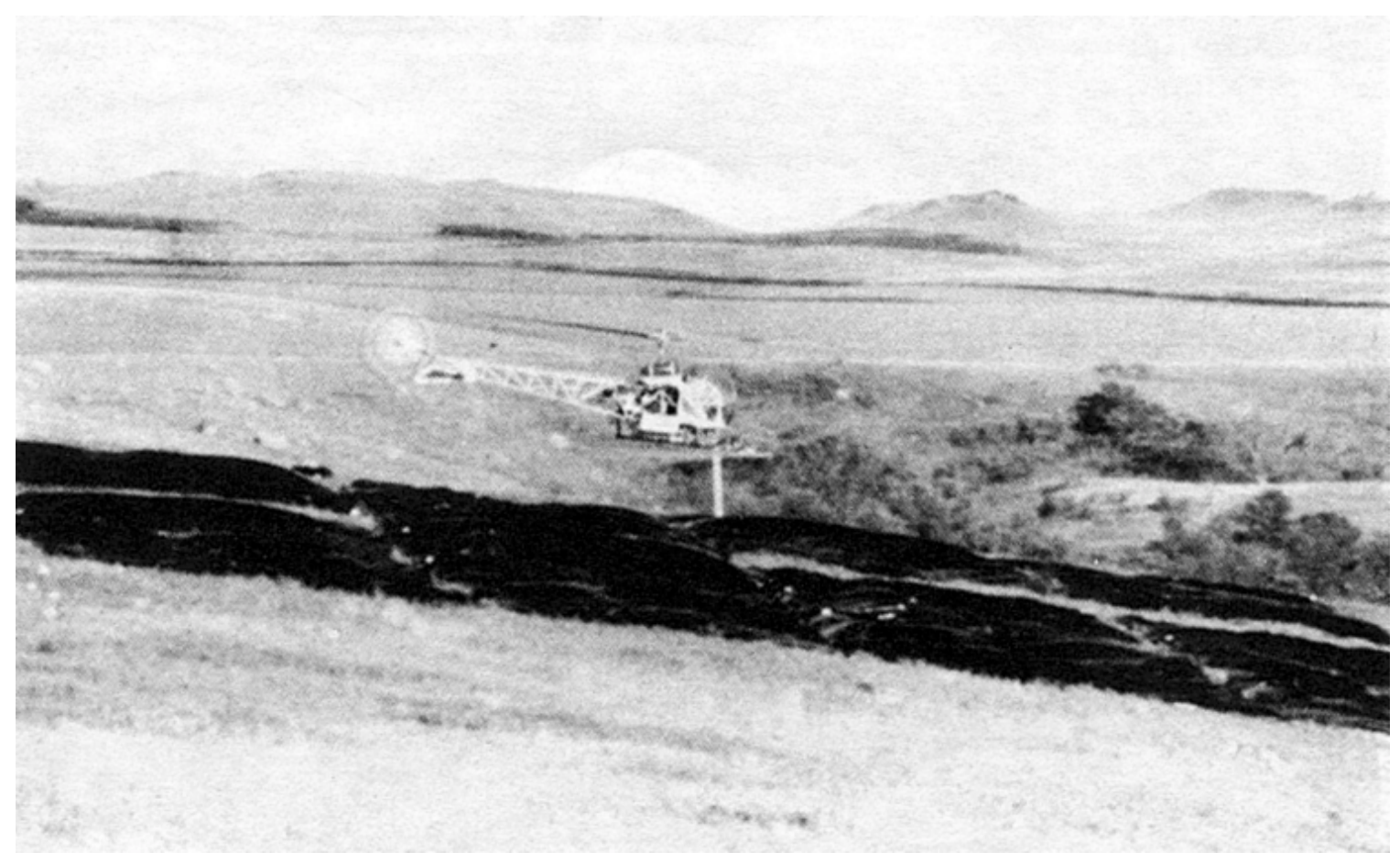

Figure 3. Herbicide application to leafy spurge following removal of plastic tarps covering specific plots.

Leafy spurge was in the true flower to seed-set growth stage and 50 to $70 \mathrm{~cm}$ tall at Kenmare and 20 to $30 \mathrm{~cm}$ tall at Mandan. Stand reduction was evaluated visually as compared to the untreated control 3 and 12 MAT by comparing leafy spurge control in treated and untreated plots. Data were subjected to analysis of variance using the general linear models procedure with the protected LSD mean separation technique.

\section{Results and discussion}

The leafy spurge was growing vigorously when treated at Kenmare. However, the spring and early summer temperatures at Mandan were above normal with generally below normal precipitation, the soil was dry, and the leafy spurge was stunted and drought stressed when treated (Table 1). Thus, the effectiveness of some treatments at the two locations differed so the data could not be combined. 
Table 1. Observed and average precipitation and temperature at Kenmare and Mandan, ND.

\begin{tabular}{|c|c|c|c|c|c|c|c|c|}
\hline \multirow[b]{3}{*}{ Date } & \multicolumn{4}{|c|}{ Precipitation } & \multicolumn{4}{|c|}{ Temperature } \\
\hline & \multicolumn{2}{|c|}{ Kenmare } & \multicolumn{2}{|c|}{ Mandan } & \multicolumn{2}{|c|}{ Kenmare } & \multicolumn{2}{|c|}{ Mandan } \\
\hline & Observed & $\begin{array}{c}\text { Percent of } \\
\text { normal }\end{array}$ & Observed & $\begin{array}{c}\text { Percent of } \\
\text { normal }\end{array}$ & Observed & $\begin{array}{l}\text { Deviation } \\
\text { from } \\
\text { normal }\end{array}$ & Observed & $\begin{array}{l}\text { Deviation } \\
\text { from } \\
\text { normal }\end{array}$ \\
\hline & $(\mathrm{cm})$ & $(\%)$ & $(\mathrm{cm})$ & $(\%)$ & (C) & (C) & (C) & (C) \\
\hline $\begin{array}{c}\text { Previous } \\
\text { year }^{\mathrm{a}}\end{array}$ & 45 & 114 & 65 & 161 & 3.7 & +0.1 & 6.2 & +0.7 \\
\hline \multicolumn{9}{|c|}{ Treatment year $^{\mathrm{b}}$} \\
\hline April & 1.8 & 47 & 1.6 & 30 & 6.8 & +2.9 & 10.3 & +5.0 \\
\hline May & 8.5 & 158 & 10.4 & 181 & 13.7 & +2.2 & 15.1 & +2.6 \\
\hline June & 5.5 & 70 & 3.9 & 44 & 13.4 & -3.3 & 20.1 & +2.3 \\
\hline July & 2.1 & 45 & 10.0 & 176 & 19.4 & -0.6 & 21.9 & +0.7 \\
\hline August & 9.5 & 205 & 12.7 & 254 & 15.3 & -3.5 & 18.0 & -2.4 \\
\hline September & 5.9 & 127 & 1.1 & 27 & 9.6 & -3.0 & 14.9 & +0.9 \\
\hline Annual & 44 & 111 & 46 & 115 & 2.6 & -1.0 & 7.7 & +2.7 \\
\hline
\end{tabular}

${ }^{\mathrm{a}} 1984$ and 1986 data for the Kenmare and Mandan locations, respectively.

${ }^{\mathrm{b}} 1985$ and 1987 data for the Kenmare and Mandan locations, respectively.

Leafy spurge control was lower at Mandan compared to Kenmare for most treatments (Table 2). Control with picloram plus 2,4-D dimethylamine at 0.28 plus $1.1 \mathrm{~kg} / \mathrm{ha}$ tractormounted sprayer (80005 nozzles) applied at Mandan averaged only 16\% 3 MAT compared to the long-term average of $68 \% 3$ MAT (4). Leafy spurge control declined rapidly at Mandan with no treatment providing satisfactory control 12 MAT. The rapid decline in leafy spurge control was expected because long term research has shown that leafy spurge control of $70 \%$ or less declines to near zero in 1 to 3 months (4). Even though the average control was lower at Mandan than Kenmare, a change in application volume, nozzle type, or picloram rate had a similar effect on leafy spurge control at both locations.

Leafy spurge control was similar at both locations when the application volume was decreased from 94 to $47 \mathrm{~L} /$ ha (Table 2). Picloram plus 2,4-D dimethylamine at 0.56 plus $1.1 \mathrm{~kg} / \mathrm{ha}$ applied at 47 and $94 \mathrm{~L} /$ ha controlled leafy spurge equally 3 and $12 \mathrm{MAT}$ at Kenmare or Mandan. Thus, decreasing the application volume to $47 \mathrm{~L} /$ ha did not affect leafy spurge control during either average or poor growing conditions. However, leafy spurge control generally was less when the application volume was decreased from 47 to $23 \mathrm{~L} /$ ha at both locations. When picloram plus 2,4-D dimethylamine at 0.56 plus 1.1 $\mathrm{kg} / \mathrm{ha}$ was applied with the one-row nozzles at 47 and $23 \mathrm{~L} / \mathrm{ha}$, leafy spurge control 12 MAT at Kenmare averaged 59 and $26 \%$, respectively. The same treatments applied at Mandan controlled leafy spurge 79 and 41\% 3 MAT, respectively. 
Table 2. Leafy spurge control with picloram plus various 2,4-D formulations applied by helicopter using a microfoil boom at Kenmare and Mandan, ND.

\begin{tabular}{|c|c|c|c|c|c|c|c|}
\hline \multirow[b]{4}{*}{ Herbicide } & \multirow[b]{4}{*}{ Rate } & \multirow[b]{4}{*}{ Volume } & \multirow[b]{4}{*}{ Nozzle type ${ }^{\mathrm{a}}$} & \multicolumn{4}{|c|}{ Location } \\
\hline & & & & \multicolumn{2}{|c|}{ Kenmare } & \multicolumn{2}{|c|}{ Mandan } \\
\hline & & & & \multicolumn{4}{|c|}{ Months after treatment } \\
\hline & & & & 2 & 12 & 3 & 12 \\
\hline & (kg/ha) & & & & & & \\
\hline Picloram + 2,4-D dimethylamine & $0.28+1.1$ & 47 & 2-row & 97 & 4 & 21 & 4 \\
\hline Picloram + 2,4 - D mixed amine ${ }^{b}$ & $0.28+1.1$ & 47 & 2-row & 99 & 26 & 55 & 6 \\
\hline Picloram $+2,4-\mathrm{D}$ mixed amine ${ }^{\mathrm{b}}$ & $0.28+1.1$ & 23 & 1-row & 91 & 1 & 20 & 8 \\
\hline Picloram + 2,4-D mixed amine ${ }^{b}$ & $0.56+1.1$ & 47 & 2-row & 100 & 79 & 77 & 28 \\
\hline Picloram + 2,4-D oil-soluble amine ${ }^{c}$ & $0.56+1.1$ & 47 & 2-row & 99 & 38 & 96 & 43 \\
\hline Picloram + 2,4-D dimethylamine & $0.56+1.1$ & 47 & 2-row & 100 & 31 & 79 & 16 \\
\hline Picloram + 2,4-D dimethylamine & $0.56+1.1$ & 47 & 1-row & 100 & 59 & 79 & 24 \\
\hline Picloram + 2,4-D dimethylamine & $0.56+1.1$ & 23 & 1-row & 97 & 26 & 41 & 5 \\
\hline Picloram + 2,4-D dimethylamine & $0.56+1.1$ & 94 & 2-row & 99 & 42 & 82 & 29 \\
\hline Picloram + 2,4-D dimethylamine & $0.28+1.1$ & 47 & 80005 & 96 & 11 & 16 & 8 \\
\hline $\operatorname{LSD}(0.10)$ & & & & NS & 24 & 25 & 17 \\
\hline
\end{tabular}

${ }^{a}$ Microfoil boom with one or two rows of parallel nozzles except for ground application which was a conventional boom using 80005 nozzles applied with applied with a tractor-mounted sprayer.

${ }^{b}$ Mixed-amine salts of 2,4-D (2:1 dimethylamine: diethanolamine, $\left.\mathrm{v} / \mathrm{v}\right)$.

c4:1 dodecylamine: tetradecylamine $(\mathrm{v} / \mathrm{v})$ mixture.

Leafy spurge control generally was similar when herbicides were applied with the one- and two-row microfoil boom (Table 2). Leafy spurge control increased from 31 to $59 \%$ when picloram plus 2,4-D dimethylamine at 0.56 plus $1.1 \mathrm{~kg} / \mathrm{ha}$ was applied with the one-row rather than the two-row nozzles at $47 \mathrm{~L} /$ ha $12 \mathrm{MAT}$ at Kenmare. However, control was similar when this treatment was applied with the one- or two-row nozzles 3 MAT at Kenmare and 3 and 12 MAT at Mandan. Generally, the one-row nozzle is used in North Dakota because maintenance is less expensive and control from the same treatment is at least as good as or better than when applied with the two-row nozzle ${ }^{8}$.

Picloram plus 2,4-D mixed amine controlled leafy spurge better than the dimethylamine or oil-soluble amine 2,4-D formulations 12 MAT at Kenmare (Table 2). Control with picloram at $0.56 \mathrm{~kg} /$ ha plus 2,4-D mixed amine averaged 79\% $12 \mathrm{MAT}$ at Kenmare and was the only treatment that controlled leafy spurge all season long.

Leafy spurge control 3 MAT at Mandan was better with the 2,4-D mixed amine formulation $(55 \%)$ than with the dimethylamine formulation $(21 \%)$ when applied with picloram at 0.28 but not $0.56 \mathrm{~kg} / \mathrm{ha}$ at $47 \mathrm{~L} /$ ha (Table 2). Only picloram at $0.56 \mathrm{~kg} / \mathrm{ha}$ applied with 2,4-D oil-soluble amine satisfactorily controlled leafy spurge (96\%) 3 MAT at Mandan. At Mandan picloram plus 2,4-D oil-soluble amine controlled leafy spurge $43 \% 12$

\footnotetext{
${ }^{8}$ N.D. Weed Control Association. 1988. Personal communication.
} 
MAT, compared to 28 and $16 \%$ with 2,4-D mixed amine and dimethylamine, respectively, at the same application rates and carrier volumes. Enhanced leafy spurge control with the oil-soluble amine formulation may be due to greater 2,4-D absorption compared to the dimethylamine or mixed amine formulations, especially with the dry conditions and sandy soil at Mandan (9).

Picloram plus 2,4-D dimethylamine at 0.28 plus $1.1 \mathrm{~kg} / \mathrm{ha}$ applied with the tractormounted sprayer (80005 nozzles) averaged only $11 \%$ control 12 MAT at Kenmare (Table 2 ). This is below the long-term average of $56 \%$ control generally obtained with picloram plus 2,4-D at 0.28 plus $1.1 \mathrm{~kg} / \mathrm{ha}$ (4). The low control level probably was because these experiments were established in very dense and mature leafy spurge stands that generally require more herbicide than moderate infestations for similar leafy spurge control $(4,6)$. Thus, the control from the aerial treatments are probably lower than would be expected if applied on less dense infestations.

Based on the results of this experiment, the most common aerial treatment for leafy spurge control in North Dakota is now picloram at 0.28 to 0.56 plus $2,4-\mathrm{D}$ at $1.1 \mathrm{~kg} / \mathrm{ha}$ applied using $47 \mathrm{~L} / \mathrm{ha}$ water and single-row nozzles. Treatments are applied annually for 3 to 4 years to obtain $90 \%$ or more control. Thus, application costs are reduced 40 to $50 \%$ because nearly twice the number of hectares can be treated per hour using 47 rather than $94 \mathrm{~L} /$ ha carrier volume. Which 2,4-D formulation used varies by county, based on individual weed control officer's experience and preference.

\section{Acknowledgments}

Dow Chemical Co., PBI-Gordon Corp., and Union Carbide Ag. Products supplied herbicides and financial assistance. The following provided technical assistance during the herbicide application without which this study could not have been conducted; Kathy Christianson, Jay Fisher, and Orval Swenson, N.D. State Univ.; Mary McKone, Ken McMartin, Robin Merrill, and Mark Peterson, Dow Chemical Co.; Chris Olson and Ann Wiese, Union Carbide Ag. Products; David Austin, PBI-Gordon Corp.; Loren Andreson and Albert Steffenson, N.D. Weed Control Association; Jim and Shawn Morton, Dakota Helicopters, Inc.; Hank McNeel, Bureau of Land Management; and Keith Johnson, E.I. du Pont de Nemours and Co.

\section{Literature cited}

1. Kirch, J. H. 1971. The microfoil boom. Arborist's News 36(1):9a-11a.

2. Kirch, J. F., J. E. Waldrum, and P. W. Bishop. 1969. The microfoil, an aerial device for controlling drift from conventional sprays. Proc. South. Weed Sci. Soc. 22:385-388.

3. Lym, R. G. and C. G. Messersmith. 1982. 2,4-D dimethylamine SULV for leafy spurge control. Res. Rep. North Cent. Weed Control Conf. 39:65.

4. Lym, R. G. and C. G. Messersmith. 1985. Leafy spurge control with herbicides in North Dakota: 20year summary. J. Range Manage. 38:149-154.

Page 8 of 9 
5. Lym, R. G. and C. G. Messersmith. 1985. Leafy spurge control and improved forage production with herbicides. J. Range Manage. 38:386-391.

6. Lym, R. G. and C. G. Messersmith. 1987. Leafy spurge control and herbicide residue from annual picloram and 2,4-D application. J. Range Manage. 40:194-198.

7. Lym, R. G. and C. G. Messersmith. 1987. Leafy spurge control with picloram plus dicamba or various 2,4-D formulations. Res. Rep. North Cent. Weed Control Conf. 44:89.

8. Messersmith, C. G. and R. G. Lym. 1983. Distribution and economic impacts of leafy spurge in North Dakota. N.D. Farm Res. 40(5):8-13.

9. Richardson, R. G. 1977. A review of foliar absorption and translocation of 2,4-D and 2,4,5-T. Weed Res. 17:259-272. 